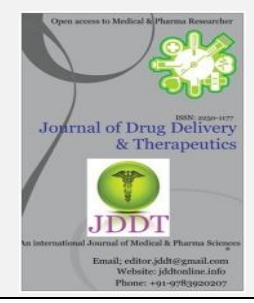

Open Access

Research Article

\title{
WOUND HEALING POTENTIAL OF METHANOLIC EXTRACT OF FLOWERS OF BUTEA MONOSPERMA LINN. IN DIABETIC ANIMALS
}

\author{
Shweta Panwar $^{1 *}$, Neetesh Kumar Jain ${ }^{1}$, M.K. Gupta ${ }^{2}$ \\ ${ }^{1 *}$ Department of Pharmacology, OCPR, Oriental University, Indore, India \\ ${ }^{2}$ Department of Pharmacy (OCPR), Oriental University, Indore, India
}

\begin{abstract}
The main of our study is to evaluate the Wound Healing Potential of Methanolic Extract of Flowers of Butea monosperma Linn. in Diabetic Animals. Methanolic extract was prepared by continuous hot extraction method by soxhlet apparatus. Preliminary phytochemical screening showed the presence of flavonoids, phenolic compounds and some glycosides. Diabetes was induced by single injection of Alloxan monohydrate in Wistar albino rats and their blood glucose levels were measured. Excision wound model was used for creation of wound in diabetic animals and methanolic extract was administered in diabetic animals to observe its effect. Methanolic extract significantly lowered the blood glucose level and highly significantly showed wound contraction in diabetic animals. The preliminary phytochemical analysis of the Butea monosperma flower extract showed the presence of tannins, flavonoids and triterpenoids. As per previous literature survey, flavonoids are responsible for anti-diabetic and wound healing activity. So this wound healing effect of Butea monosperma may be due to presence of flavonoids in plant. Hence present research supports traditional claims of the plant in wound healing.
\end{abstract}

Keywords: Butea monosperma, Diabetic animals, Alloxan monohydrate, Methanolic Extract, Wound Area

Article Info: Received 12 Sep, 2018; Review Completed 07 Oct 2018; Accepted 08 Oct 2018; Available online 15 Oct 2018

\section{Cite this article as:}

Panwar S, Jain NK, Gupta MK, Wound Healing Potential of Methanolic Extract of Flowers of Butea monosperma Linn. in Diabetic Animals, Journal of Drug Delivery and Therapeutics. 2018; 8(5-s):306-310

DOI: http://dx.doi.org/10.22270/jddt.v8i5-s.1979

口. *Address for Correspondence:

Shweta Panwar, PG Research Scholar, Department of Pharmacology, OCPR, Oriental University, Indore-India

\section{INTRODUCTION}

Diabetes has been recognized as a major health problem worldwide for the twenty-first century. India leads the world with largest number of diabetic subjects thus earning the dubious distinction of being termed the "Diabetes Capital of the World"' (Mohan et al., 2007).

Glycemic control is fundamental to management of diabetes. Random clinical trials have shown that achieving glycemic control is associated with decreased rates of complications such as retinopathy, neuropathy, nephropathy, cardiovascular diseases etc ${ }^{2}$ (Fuller et al., 1979; Kannel and Mcgee, 1979).

Wound healing or wound repair, is the body's natural process of regenerating dermal and epidermal tissue. When an individual is wounded, a set of complex biochemical events takes place in a closely orchestrated cascade to repair the damage. These events overlap in time and may be artificially categorized into separate steps: the inflammatory, proliferate and remodeling phases $^{3}$. (Stadelmann et al., 1998)

In traditional system of medicines, various medicinal plants were used for the treatment of early stage and late stage of diabetes as well as its various complications. Butea monosperma is the well documented medicinal plants that have been extensively used in treatment of diabetes and wound healing which is delayed in the diabetes.

Since there are no scientific reports on its traditional use, so our main aim is to evaluate the effect of polar extracts on diabetic wound healing. 


\section{MATERIALS AND METHODS}

\section{Plant Materials Collection \& Authentification}

The flowers of Butea monosperma were collected in the month of March from local area of Mandsaur. All the plant materials were taxonomically identified by senior Botanist and herbarium sheets were submitted in School of Studies in Botany, Vikram University, Ujjain under voucher specimen number SI1/2018.

\section{Preparation of Total Crude Extract}

The flowers were dried under shade and subjected to coarse powder for extraction process. Dried flowers of Butea monosperma was extracted using methanol by soxhlet apparatus for $72 \mathrm{~h}$. The Methanolic extracts were dried completely under reduced pressure. After drying, the respective extracts were weighed and percentage yield was determined ${ }^{4}$ (Mukherjee, 2002).

\section{Preliminary In-Vivo Anti-Diabetic Activity}

\section{Selection of animals}

Wistar albino rats of either sex between 2 and 3 months of age weighing 150-200 $\mathrm{g}$ were used which were procured from the central animal house facility of Pharmacology Department. All animals were housed in an animal room under normal condition of $25 \pm 1{ }^{\circ} \mathrm{C}, 12$-h light and dark cycle. The animals were allowed free to access commercial rat pallet diet and water ad libitum. The study protocol was designed and approved by the IAEC/CPCSEA.

\section{Acute toxicity studies}

The acute oral toxicity studies were carried out according to the guidelines set by the Organization for Economic Co-operation and Development (OECD), revised draft guideline $423^{5}$ (OECD guidelines, 2001).

\section{Induction of Diabetes:}

The animals were then injected with a single dose of alloxan monohydrate $(120 \mathrm{mg} / \mathrm{kg})$ in cold normal saline solution (freshly prepared) in abdominal cavity by I.P. route to induce diabetes. Control animals were injected with normal saline solution. Fasting blood glucose levels were measured three days later to confirm the diabetic status of the animals. For blood glucose measurements blood samples were drawn from the tail vein \& determined by glucometer strips based on glucose oxidase method ${ }^{6}$. (Nayak \& Shivanda, 2007)

The treatment schedule was as follows.

Group-I, Normal control animals

Group-II, Diabetic control animals (alloxan monohydrate $(120 \mathrm{mg} / \mathrm{kg}))$

Group-III, Diabetic control animals + methanolic extract in a dose of $200 \mathrm{mg} / \mathrm{kg}$

Group-IV, Diabetic control animals + methanolic extract in a dose of $400 \mathrm{mg} / \mathrm{kg}$

Group-V, Diabetic control animals + glibenclamide $\mathrm{n}$ a dose of $5 \mathrm{mg} / \mathrm{kg}$

\section{Excision Wound Model:}

\section{Preparation of methanolic extract ointment:}

$20 \%$ w/w ointment of flower extract was prepared by mixing $20 \mathrm{gm}$. of methanolic extract in $80 \mathrm{gm}$ of white petroleum jelly using pestle and mortar.

\section{Procedure of wound creation:}

Animals were anaesthetized with ether and hairs were removed on both sides of back by scissors. The area of the wound to be created was outlined on back of animals with methylene blue using a circular stainless steel stencil. A full thickness excision wound of circular area was created along markings. The entire wound was left open. Animals were closely observed for any infection and those which showed signs of infection were separated and excluded from study.

Animals were divided into five groups and each group consists of 6 rats.

1. Group I: Normal control applied with Vaseline.

2. Group II: Normal experimental applied with test drug extract ointment.

3. Group III: Diabetic control, applied with Vaseline.

4. Group IV: Diabetic experimental, applied with test drug extract ointment.

5. Group V: Positive control, applied with soframycin ointment.

Wound areas were measured on different days for all groups by making replicas using transparent sheet and permanent marker. Recording of wound area were measured on graph paper ${ }^{6}$. (Nayak \& Shivanda, 2007)

Percent wound closure was calculated by following formula.

\section{$\%$ wound closure $=$}

Wound area on zero day - wound area on N day X 100 Wound area on zero day

Where: $\mathrm{N}$ is No of days.

\section{Statistical analysis}

All data were expressed as mean \pm standard error of mean (S.E.M). Statistical analysis was performed by one way ANOVAs followed by Dunnets $t$-test (Graph pad prism 5.0) and $P<0.05$ was considered to be significant.

\section{RESULTS}

\section{Extractive Value Determination}

Dried flowers of Butea monosperma was extracted by methanol. The percentage yields of all dried extracts were determined by using the following formula.

$$
\begin{aligned}
& \text { Weight of Extract } \\
& \% \text { yield = ----------------------------- x } 100
\end{aligned}
$$


Table 1: Different extracts with their appearance and \% yield (in gm)

\begin{tabular}{|c|c|c|c|c|}
\hline $\begin{array}{c}\text { S. } \\
\text { No. }\end{array}$ & Extracts & $\begin{array}{c}\text { Color of dried } \\
\text { extracts }\end{array}$ & $\begin{array}{c}\text { Consistency of } \\
\text { dried extracts }\end{array}$ & $\begin{array}{c}\text { \% Yield } \\
(\mathbf{W} / \mathbf{W})\end{array}$ \\
\hline 1. & $\begin{array}{c}\text { Methanolic extracts of Butea } \\
\text { monosperma }\end{array}$ & Dark Orange & Sticky & $18 \%$ \\
\hline
\end{tabular}

\section{Preliminary Phytochemical Screening}

The preliminary phytochemical analysis revealed that the presence of alkaloids, flavonoids, phenolic compounds and some glycosides in methanolic extracts.

\section{Acute Toxicity Studies of Plant Extracts}

No toxic effects were observed at a higher dose of 2000 $\mathrm{mg} / \mathrm{kg}$ body weight of Wistar rats. The cut off value of 200 and $1 / 5$ dose double of $400 \mathrm{mg} / \mathrm{kg}$ were selected for pharmacological evaluation.

Table 2: Acute toxicity studies of plant extract

\begin{tabular}{|c|c|c|c|c|c|c|c|}
\hline S. & Treatment & \multirow{2}{*}{$\begin{array}{c}\text { Dose } \\
\text { No. }\end{array}$} & Number of & \multicolumn{3}{|c|}{ Mortality } & Toxicity \\
\cline { 5 - 6 } & & & animals & $\begin{array}{c}\text { After 24 } \\
\text { hrs }\end{array}$ & $\begin{array}{c}\text { After 7 } \\
\text { days }\end{array}$ & $\begin{array}{c}\text { After 14 } \\
\text { days }\end{array}$ & \\
\hline 3 & $\begin{array}{c}\text { Butea monosperma } \\
\text { (methanolic extract) }\end{array}$ & 2000 & 5 & 0 & 0 & 0 & Safe \\
\hline
\end{tabular}

\section{Alloxan induced antidiabetic activity of Butea monosperma}

\section{Effect on Blood glucose level}

The induction of diabetes with alloxan monohydrate increases the blood glucose level significantly $(p<0.001)$ in group II rats as compared to normal rats. In 21 day study glibenclamide the standard drug restored the blood glucose highly significantly with the $p<0.001$ in 14 days whereas methanolic extract $(200 \& 400 \mathrm{mg} / \mathrm{kg})$ reduced the glucose level moderately and highly significant with $p<0.01 \& p<0.001$ on $14^{\text {th }}$ and $21^{\text {st }}$ days. The results are shown in Table No 3.

Table 3: Effect of methanolic extracts on glucose level in alloxan induced diabetic rats

\begin{tabular}{|c|c|c|c|c|c|c|}
\hline \multirow{3}{*}{$\begin{array}{c}\text { Group } \\
\text { No }\end{array}$} & \multirow[t]{3}{*}{ Group } & \multicolumn{5}{|c|}{ Blood Sugar level } \\
\hline & & \multicolumn{5}{|c|}{ Long Term Study (Days) } \\
\hline & & $\begin{array}{c}\text { Before } \\
\text { inducing } \\
\text { Diabetes }\end{array}$ & 3 & 7 & 14 & 21 \\
\hline I & Normal control & $80.3 \pm 0.66$ & $81.3 \pm 0.27$ & $82.1 \pm 1.37$ & $81.5 \pm 2.14$ & $81.21 \pm 2.18$ \\
\hline II & Diabetic control & $82.4 \pm 2.31$ & $242.4 \pm 2.69$ & $275.1 \pm 3.23 * * *$ & $266.3 \pm 2.47^{* * * *}$ & $291.1 \pm 3.11^{* * * *}$ \\
\hline III & $\begin{array}{l}\text { Methanolic extract } \\
(200 \mathrm{mg} / \mathrm{kg})\end{array}$ & $82.17 \pm 2.29$ & $243.4 \pm 2.55$ & $215.2 \pm 2.21 * * *$ & $201.8 \pm 3.68 * * *$ & $196.2 \pm 2.49 * * *$ \\
\hline IV & $\begin{array}{l}\text { Methanolic extract } \\
(400 \mathrm{mg} / \mathrm{kg})\end{array}$ & $82.18 \pm 1.29$ & $244.2 \pm 2.29$ & $207.2 \pm 2.41 * * *$ & $193.6 \pm 2.32 * * *$ & $173.3 \pm 2.82 * * *$ \\
\hline $\mathrm{V}$ & $\begin{array}{l}\text { Glibernclamide } \\
(5 \mathrm{mg} / \mathrm{kg})\end{array}$ & $82.32 \pm 3.17$ & $243.2 \pm 2.41$ & $198.1 \pm 3.24 * *$ & $168.3 \pm 2.57 * * *$ & $159.4 \pm 2.54 * * *$ \\
\hline
\end{tabular}

Where- $* p<0.05, * * p<0.01, * * * p<0.001$ compared with diabetic control vs treated groups

\section{Excision Wound model}

Wound Area:

Significant increase in wound healing was observed in methanolic extract treated Group-II (normal treated) \& Group-IV (Diabetic treated) animals. Animals of groupII (normal treated) and group-IV (Diabetic treated) showed a increased percentage of wound contraction when compared with the animals of group-I (normal control), group-III (Diabetic Control) and group-V (positive Control).On $11^{\text {th }}$ day the normal treated (Group-II) animals showed highly significant wound contraction comparable with wound of normal control (Group-I) animals . On $11^{\text {th }}$ day, the diabetic treated (Group-IV) animals showed highly significant wound contraction comparable with wound of Diabetic control (Group-III) animals. The wound contraction results of extract animals were almost similar with positive control (Group-V). 
Table 4: Wound Area (Excision wound model)

\begin{tabular}{|l|l|l|l|l|l|}
\hline Day & $\begin{array}{l}\text { Group-I } \\
\text { Normal } \\
\text { Control }\end{array}$ & $\begin{array}{l}\text { Group-II } \\
\text { Normal control } \\
\text { treated by Vaseline }\end{array}$ & $\begin{array}{l}\text { Group-III } \\
\text { Diabetic Control }\end{array}$ & $\begin{array}{l}\text { Group-IV } \\
\text { Diabetic control treated by } \\
\text { methanolic extract }\end{array}$ & $\begin{array}{l}\text { Group-V } \\
\text { Diabetic control treated } \\
\text { by soframycin ointment }\end{array}$ \\
\hline Zero & $65.22 \pm 3.22$ & $67.35 \pm 3.31$ & $66.56 \pm 3.45$ & $65.32 \pm 3.44$ & $66.76 \pm 3.12$ \\
\hline $\mathbf{5}^{\text {th }}$ & $67.34 \pm 3.44$ & $65.78 \pm 3.87$ & $68.42 \pm 2.24 *$ & $51.44 \pm 3.82 * *$ & $49.57 \pm 3.21 * *$ \\
\hline $\mathbf{1 1}^{\text {th }}$ & $66.76 \pm 3.48$ & $60.77 \pm 3.89 *$ & $70.55 \pm 2.78 *$ & $22.61 \pm 3.56 * * *$ \\
\hline \multicolumn{4}{|c|}{ Where- $* p<0.05, * * p<0.01, * * * p<0.001$ compared with diabetic control vs treated groups } \\
\hline
\end{tabular}

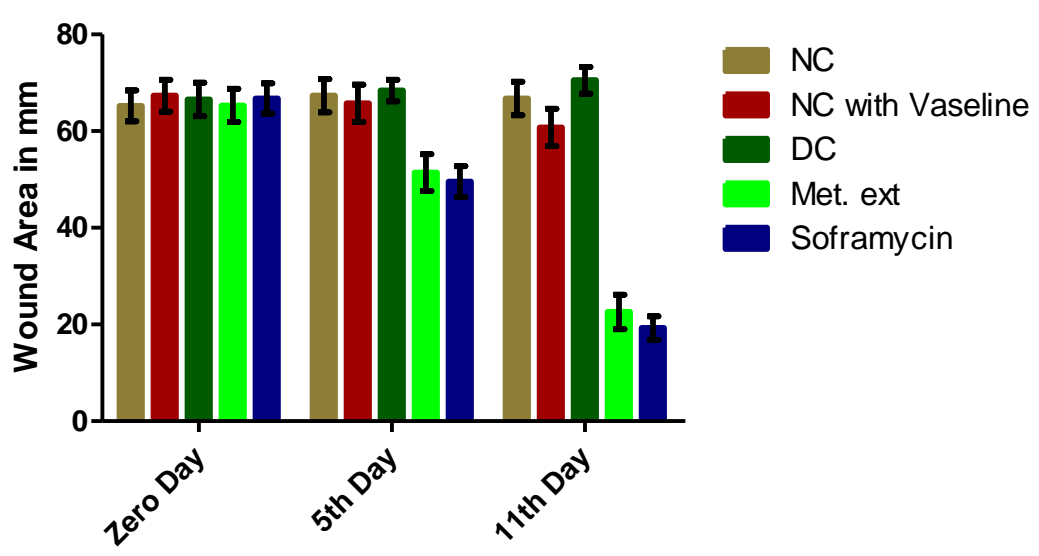

Figure 1: Effect of methanolic extract on wound area in $\mathrm{mm}$

\section{DISCUSSION}

Non-insulin dependent diabetes mellitus (NIDDM) is a multifactorial disease, which is characterized by hyperglycemia and lipoprotein abnormalities. This individuality are hypothesized to be accountable for damage to cell membranes through non-enzymatic glycosylation of proteins, auto-oxidation of glucose or increase metabolism of glucose by the sorbitol-polyol pathway. Cell compensation will in turn, result in prominent construction of reactive oxygen species or ROS. High levels of ROS have been established to play a role in the pathogenesis of $\operatorname{NIDDM}^{7}$ (Al-Qattan et al., 2008).

Traditionally, there are a variety of herbs are being used for the handling of diabetes mellitus, from which simply some have been evaluated as per the modern system of medicine. Most of the reported plants give the impression to act directly on pancreas and stimulate insulin release in the blood. Some will positively alter the activities of regulatory enzymes of glycolysis, gluconeogenesis and other pathways by the stage directly on tissues like liver, muscle and fat (extrapancreatic effect).Chemical constituents of these plants are recognized to possess wide range of medicinal properties.

The methanolic extract produced a marked decrease in blood glucose levels at $200 \mathrm{mg} / \mathrm{kg}$ and $400 \mathrm{mg} / \mathrm{kg}$ body weight in alloxan induced diabetic rats after 21 days treatment. The antidiabetic effect Butea monosperma may be due to augmented discharge of insulin from the existing $\beta$-cells of pancreas similar to that experimental after glibenclamide administration.

Wound healing procedure consists of different phases such as granulation, collagenization, collagen maturation and scar maturation which are simultaneous but selfgoverning to each other. Hence in this study two different models were used to assess the effect of methanolic extract and butanolic fraction on various phases. The result of the present study showed that Butea monosperma possesses a definite prohealing action especially in diabetic animals. In excision wound healing model the methanolic extract of the flower of the plant showed considerable augment in percentage closure of excision wounds by enhance depithelization. This improve depithelization may be due to the effect of Butea monosperma extracts on enhanced collagen synthesis. Deposition of newly synthesized collagens at the wound site increases the collagen concentration per unit area and hence the tissue tensile $\operatorname{strength}^{8}$ (Udupa $e t$ al., 1995).

\section{CONCLUSION}

The preliminary phytochemical analysis of the Butea monosperma flower extract showed the presence of tannins, flavonoids and triterpenoids. As per previous literature survey, flavonoids are responsible for antidiabetic and wound healing activity. So this wound healing effect of Butea monosperma may be due to presence of flavonoids in plant. Hence present research supports traditional claims of the plant in wound healing. 


\section{REFERENCES}

1. Mohan V, Sandeep S, Deepa R, Shah B, Varghese C. Epidemiology of type 2 diabetes: Indian scenario. Indian Journal of Medical Research 2007; 125: 217-230.

2. Fuller JH, Keen H, Jarrett RJ, Omer T, Meade TW, Chakrabarti R, North WRS, Stirling Y. Haemostatic variables associated with diabetes and its complications. British Medical Journal 1979; 2:964-966.

3. Stadelmann W.K., Digenis A.G. and Tobin G.R. Physiology and healing dynamics of chronic cutaneous wounds. The American Journal of Surgery, 1998; 176(2):26S-38S.

4. Mukherjee P.K., 2002. Quality Control of Herbal Drugs-an Approach to Evaluation of Botanicals. New Delhi, Business Horizons Pharmaceutical Publishers.

5. OECD Guidelines 2001. "Guidance document on acute oral toxicity testing" Series on testing and assessment No. 23, Organization for Economic Co-operation and Development,
OECD Environment, health and safety publications, Paris Available from: http://www. Oecd.org/ehs [accessed 20 March on 2010].

6. Nayak B., Shivanda Maharaj D., "Wound Healing Activity of Carica Papaya Linn. In experimentally induced diabetic rats", Indian Journal of Experimental Biology. 2007; 45:739743.

7. Al-Qattan K, Martha Thomson a, Muslim Ali, Garlic (Allium sativum) and ginger (Zingiber officinale) attenuate structural nephropathy progression in streptozotocin-induced diabetic rats. The European e-Journal of Clinical Nutrition and Metabolism 2008; 3:e62-e71.

8. Udupa D., Kulkarni R., Udupa S.L. Effect of Tridax procumbens extracts on wound healing. International Journal of Pharmacology 1995; 33:37-40. 